University of Nebraska - Lincoln

DigitalCommons@University of Nebraska - Lincoln

Agronomy \& Horticulture -- Faculty Publications

Agronomy and Horticulture Department

2019

\title{
Dedicated Bioenergy Crops and Water Erosion
}

\author{
Bharat Sharma Acharya \\ University of Nebraska-Lincoln, bikatiaas@gmail.com \\ Humberto Blanco-Canqui \\ University of Nebraska-Lincoln, hblanco2@unl.edu \\ Robert B. Mitchell \\ USDA, Agricultural Research Service \\ Richard Cruse \\ lowa State University, rmc@iastate.edu \\ David Laird \\ lowa State University, dalaird@iastate.edu
}

Follow this and additional works at: https://digitalcommons.unl.edu/agronomyfacpub

Part of the Agricultural Science Commons, Agriculture Commons, Agronomy and Crop Sciences Commons, Botany Commons, Horticulture Commons, Other Plant Sciences Commons, and the Plant Biology Commons

Acharya, Bharat Sharma; Blanco-Canqui, Humberto; Mitchell, Robert B.; Cruse, Richard; and Laird, David, "Dedicated Bioenergy Crops and Water Erosion" (2019). Agronomy \& Horticulture -- Faculty Publications. 1296.

https://digitalcommons.unl.edu/agronomyfacpub/1296

This Article is brought to you for free and open access by the Agronomy and Horticulture Department at DigitalCommons@University of Nebraska - Lincoln. It has been accepted for inclusion in Agronomy \& Horticulture -Faculty Publications by an authorized administrator of DigitalCommons@University of Nebraska - Lincoln. 


\title{
Dedicated Bioenergy Crops and Water Erosion
}

\author{
Bharat Sharma Acharya, ${ }^{*}$ Humberto Blanco-Canqui, Robert B. Mitchell, Richard Cruse, and David Laird
}

\begin{abstract}
Information on the water quality impact of perennial warmseason grasses (WSGs) when grown in marginal lands as dedicated energy crops is limited. We studied how WSGs affected runoff, sediment, and nutrient losses and related near-surface soil properties to those of no-till corn (Zea mays L.) on an eroded soil in southwestern lowa and a center pivot corner in east-central Nebraska. The experiment at the eroded soil was established in 2012, and treatments included 'Liberty' switchgrass (Panicum virgatum L.) and no-till continuous corn. The experiment at the pivot corner was established in 2013 with 'Liberty' switchgrass, 'Shawnee' switchgrass, low-diversity grass mixture, and corn. We simulated rainfall at $63.5 \pm 2.8 \mathrm{~mm} \mathrm{~h}^{-1}$ for $1 \mathrm{~h}$ to portray 5 -yr return periods and measured water erosion in spring 2017. Time to runoff start and runoff depth did not differ between WSGs and corn. On the eroded soil, sediment and nutrient losses did not differ between treatments. At the pivot corner, sediment ( $0.71 \mathrm{vs}$. $\left.0.15 \mathrm{Mg} \mathrm{ha}^{-1}\right)$ and $\mathrm{PO}_{4}-\mathrm{P}\left(0.037\right.$ vs. $\left.0.006 \mathrm{~kg} \mathrm{ha}^{-1}\right)$ losses were five times higher in corn than in WSGs. Near-surface soil properties did not differ on the eroded soil, but at the pivot corner, wet aggregate stability was four times higher and residue cover was $34 \%$ higher in WSGs than in corn. Water-stable aggregates were negatively correlated with $\mathrm{NO}_{3}-\mathrm{N}$ and $\mathrm{PO}_{4}-\mathrm{P}$ losses. Overall, WSGs can improve water quality in marginally productive croplands, but their effectiveness appears to be site specific.
\end{abstract}

\section{Core Ideas}

- Warm-season grasses did not reduce runoff depth compared with corn.

- Warm-season grasses on a center pivot corner reduced sediment and nutrient loss compared with corn.

- Sediment loss between corn and switchgrass grown in an eroded soil did not differ.

- Warm-season grass effectiveness to reduce water erosion can be site specific.

This document is a U.S. government work and is not subject to copyright in the United States.

Copyright $\odot$ American Society of Agronomy, Crop Science Society of America, and Soil Science Society of America. 5585 Guilford Rd., Madison, WI 53711 USA.

All rights reserved.

J. Environ. Qual. 48:485-492 (2019)

doi:10.2134/jeq2018.10.0380

Received 25 Oct. 2018.

Accepted 16 Nov. 2018

*Corresponding author (bsacharya@agcenter.lsu.edu).
A NNUAL ROW CROP PRODUCTION for grain and cellulosic biofuel is associated with risks of surface runoff, transport of sediment, and nutrient losses to water bodies (Schilling et al., 2008). Sediment and nutrient addition to water bodies through agricultural nonpoint-source pollution is an ongoing concern, particularly in the US Midwest (Porter et al., 2015; Stackpoole et al., 2017). The Midwest states account for nearly $75 \%$ of nutrients entering the Gulf of Mexico. The high losses of nutrients have been linked to the development of hypoxic zones (USEPA, 2007; Porter et al., 2015). Nutrient and sediment loading into the water bodies can be in part accelerated by climatic fluctuations with localized and intense storm events, which can lead to increased soil erosion (Morton et al., 2015; Jiang et al., 2016).

Existing management practices may not be adequate to control water erosion under heavy rainstorms $(\geq 76.2 \mathrm{~mm}$ in a single day; Saunders et al., 2012). Thus, improved management strategies are needed to reduce loss of agricultural nonpoint-source pollutants. Establishing warm-season grasses (WSGs) such as switchgrass (Panicum virgatum L.) in marginally productive croplands could be a potential strategy to reduce nutrient and sediment loss from agricultural systems (Acharya and Blanco-Canqui, 2018). VanLoocke et al. (2017) used a modeling approach and reported that establishment of miscanthus (Miscanthus $\times$ giganteus J.M. Greef \& Deuter ex Hodkinson \& Renvoize) and switchgrass can reduce the transport of dissolved inorganic $N$ to the Gulf of Mexico. Marginally productive croplands are marginal soils with relatively lower productivity than prime croplands, which may include compacted soils, acidic and saline soils, flood-prone soils, and even center pivot corners (Blanco-Canqui et al., 2016). Mitchell et al. (2012) stated that "marginally productive cropland for the western Corn Belt are sites that are more than 25\% below the average dryland maize production for the county." It is estimated that cellulosic bioenergy crops such as WSGs grown in marginally productive land of 10 Midwestern US states can supply nearly $63 \mathrm{GJ} \mathrm{ha}^{-1}$ of ethanol annually (Gelfand et al., 2013).

Field data on water quality impacts of growing dedicated bioenergy crops such as switchgrass are limited. However, the few studies under WSGs when used as conservation buffers such as grass hedges, filter strips, and riparian buffers suggest that growing WSGs as dedicated bioenergy crops could reduce water

B.S. Acharya and H. Blanco-Canqui, Dep. of Agronomy and Horticulture, Univ. of Nebraska, Lincoln, NE 68583; R.B. Mitchell, USDA-ARS Wheat, Sorghum and Forage Research Unit, 251 Filley Hall, Lincoln, NE 68583; R. Cruse and D. Laird, Agronomy Dep., lowa State Univ., Ames, IA 50011. Assigned to Associate Editor Jian Liu. 
erosion and improve water quality parameters (Lee et al., 2003; Helmers et al., 2012; Zhou et al., 2014). Perennial WSGs have deeper root systems and higher root biomass and annual productivity than row crops such as corn (Zea mays L.). Perennial WSGs can provide uniform residue cover on the soil surface during the growing season and after crop harvest to intercept raindrops and slow surface runoff (Acharya and Blanco-Canqui, 2018). Warm-season grasses could also improve soil properties and reduce erodibility compared with row crops (Stewart et al., 2015; Zaibon et al., 2017).

Although some studies have evaluated the effect of growing WSGs on biomass production and soil properties in marginal lands (Brown et al., 2016), field data on the water quality implications of growing WSGs in marginal lands are limited. Modeling studies have reported some mixed results. Feng et al. (2015) estimated that conversion of marginal lands under cornsoybean [Glycine $\max (\mathrm{L}$.$) Merr.] to switchgrass and miscanthus$ can reduce soil erosion by 27 to $98 \%$, total $\mathrm{N}$ loss by 30 to $91 \%$, and total P loss by 65 to $76 \%$. However, Thomas et al. (2014) estimated no effect of miscanthus and switchgrass on annual runoff and $\mathrm{NO}_{3}-\mathrm{N}$ and total $\mathrm{P}$ losses compared with corn. Field data on water erosion from WSGs grown on marginal lands are needed to validate models and extrapolate results across regional scales. This field information can also contribute to the development of sustainable bioenergy production systems.

The objectives of this study were (i) to quantify the impacts of WSGs and no-till corn on runoff, sediment, and nutrient losses when these crops are grown in marginally productive lands, and (ii) to evaluate differences in runoff, sediment, and nutrient losses between a low-diversity mix of WSGs and monoculture cultivars grown in a center pivot corner. We hypothesized that (i) perennial WSGs will reduce runoff, sediment, and nutrient losses relative to corn in marginally productive croplands, and (ii) the low-diversity mix of WSGs will reduce runoff, sediment, and nutrient losses more than switchgrass monocultures.

\section{Materials and Methods Description of the Study Sites}

The study was conducted in spring 2017 in marginally productive croplands in east-central Nebraska and southwestern Iowa to examine the residual effects of energy crops. Our first study site was located at the Iowa State University Armstrong Research and Demonstration Farm near Atlantic, IA $\left(41^{\circ} 18^{\prime} 29^{\prime \prime} \mathrm{N}\right.$, $\left.95^{\circ} 10^{\prime} 19^{\prime \prime} \mathrm{W}\right)$. It has mean annual precipitation of $939 \mathrm{~mm}$ and mean annual temperature of $9.3^{\circ} \mathrm{C}$. The site is characterized as an eroded hillslope and consists of loess-derived soil (Fidel et al., 2017). The dominant soil texture includes eroded Exira silty clay loam (fine-silty, mixed, superactive, mesic Typic Hapludolls) with $<7 \%$ slope (Fidel et al., 2017). The experiment was established in 2012. Treatments were 'Liberty' switchgrass and no-till continuous corn with four replications. The treatments were arranged in a completely randomized design. The plot size was $44 \times 68 \mathrm{~m}$. Switchgrass was no-till drilled in 19-cm-wide rows at a rate of $6.7 \mathrm{~kg}$ $\mathrm{ha}^{-1}$, between rows of a corn nurse crop in May 2012. Because of the poor stand, switchgrass plots were reseeded on May 2013 at a rate of $8.6 \mathrm{~kg} \mathrm{ha}^{-1}$, but without a corn nurse crop. Switchgrass plots were surface applied with urea at a rate of $56 \mathrm{~kg} \mathrm{~N} \mathrm{ha}^{-1}$ in 2014 and 2015 , and corn plots were applied with $224 \mathrm{~kg} \mathrm{ha}^{-1}$ of $32 \% \mathrm{~N}$.
The second study site was an on-farm experiment located near Beaver Crossing in east central Nebraska $\left(40^{\circ} 43^{\prime} 42^{\prime \prime} \mathrm{N}\right.$, $\left.97^{\circ} 12^{\prime} 14^{\prime \prime} \mathrm{W}\right)$. It has mean annual precipitation of $722 \mathrm{~mm}$ and mean annual temperature of $10.5^{\circ} \mathrm{C}$. The dominant soil textures in the study site include silt loam and silty clay loam with $<7 \%$ slope (https://websoilsurvey.nrcs.usda.gov/app/). The experiment was laid out in a completely randomized design with two replicates of 'Liberty' switchgrass, 'Shawnee' switchgrass, and a low-diversity WSG mixture seeded as $45 \%$ big bluestem (Andropogon gerardii Vitman), 45\% Indiangrass [Sorghastrum nutans (L.) Nash], and $10 \%$ sideoats grama [Bouteloua curtipendula (Michx.) Torr.]. The WSG plots were planted in the spring 2013 in a center pivot corner. Center pivot corners are unirrigated field corners due to circular motion of a center pivot irrigation system. For example, a center pivot system covering 64 ha will irrigate 53 ha of area and leave four field corners $(\sim 11 \mathrm{ha})$ without irrigation (Mitchell et al., 2012; Acharya and Blanco-Canqui, 2018). The pivot corners were considered marginally productive because they are unirrigated and have $\leq 75 \%$ of the crop yield compared with the average county yield for dryland maize (Mitchell et al., 2012). The grasses were sown into soybean stubble using a no-till grassland drill (Truax) and received no fertilizer in the planting year, 2013.

The field prior to WSG establishment was under no-till corn-soybean rotation. Beginning in 2014, the WSG plots were split to accommodate two $\mathrm{N}$ fertilizer rates, 60 or $120 \mathrm{~kg}$ of $\mathrm{N}$ $\mathrm{ha}^{-1}$ each spring in 2014, 2015, and 2016. For this study, we used plots receiving $60 \mathrm{~kg} \mathrm{~N} \mathrm{ha}^{-1}$, and corn-soybean crop rotation adjacent to WSG treatments. The corn-soybean rotation was not randomized with WSG treatments to facilitate management operations and avoid edge effects on the treatments. Rainfall was simulated during the corn phase of the rotation (corn residues) as described below. The field during the corn phase received $82 \mathrm{~kg}$ of $\mathrm{N} \mathrm{ha}^{-1}$ in 2014 and 2016.

In this paper, data on WSG biomass are not reported, as our study focused primarily on water erosion. However, as discussed below, we report data on residue cover, which can directly affect water erosion. Data on WSG biomass for both sites will be reported in a companion paper.

\section{Rainfall Simulation and Water Erosion Measurements}

Rainfall was simulated in late spring 2017 to determine the effects of WSGs and no-till corn on water quality parameters. Dry and wet rainfall simulation runs were performed at both sites. Dry runs, $24 \mathrm{~h}$ prior to wet simulation, were performed for $30 \mathrm{~min}$ at intensity of $63.5 \mathrm{~mm} \mathrm{~h}^{-1}$ (similar to Blanco-Canqui et al., 2016) to reduce differences in antecedent soil moisture before water erosion measurement. Wet simulation was performed in the same plots for $1 \mathrm{~h}$ to conduct water erosion measurements. Soil gravimetric water content prior to the wet run did not differ among treatments at any site. Mean gravimetric water content of the soil for the 0 - to 10 -cm depth was $0.35 \pm 0.04 \mathrm{~g} \mathrm{~g}^{-1}$ (mean $\pm \mathrm{SD}$ ) on the eroded soil and $0.27 \pm 0.02 \mathrm{~g} \mathrm{~g}^{-1}$ at the pivot corner. The soil slope was $6.4 \pm 1.5 \%$ on the eroded soil and $4.6 \pm 1.3 \%$ at the pivot corner.

We used a portable rainfall simulator with $3-\mathrm{m} \times 3-\mathrm{m}$ area made up of aluminum (Humphry et al., 2002). Briefly, the simulator consists of a 1/2 HH-SS50WSQ single nozzle at the center of the top of frame (Spraying Systems Company), which simulates rain from $\sim 2.5 \mathrm{~m}$ above the ground. The aluminum frames are assembled and dissembled using locking pins in angle fittings 
(Humphry et al., 2002). The simulator consists of an in-line filter to prevent nozzle clogging, a pressure regulator, a flow meter, and a pressure gauge to control flow.

Wet simulations were performed at an intensity of $63.5 \mathrm{~mm} \mathrm{~h}^{-1}$ for $1 \mathrm{~h}$ to portray return periods of $5 \mathrm{yr}$ at both sites. Tarps were used around the frame of the simulator to minimize wind drift during runs. Water used for rainfall simulation on the eroded soil had an electrical conductivity of $0.45 \mathrm{dS} \mathrm{m}^{-1}, \mathrm{pH}$ of 7.1 , total dissolved solid of $269 \mathrm{mg} \mathrm{L}^{-1}$, total $\mathrm{N}$ of $0.2 \mathrm{mg} \mathrm{L}^{-1}$, total $\mathrm{P}$ of $0.03 \mathrm{mg}$ $\mathrm{L}^{-1}, \mathrm{NO}_{3}-\mathrm{N}$ of $0.1 \mathrm{mg} \mathrm{L}^{-1}, \mathrm{NH}_{4}-\mathrm{N}$ of $<0.1 \mathrm{mg} \mathrm{L}^{-1}$, and $\mathrm{PO}_{4}-\mathrm{P}$ of $0.03 \mathrm{mg} \mathrm{L}^{-1}$. Water used for rainfall simulation at the pivot corner had an electrical conductivity of $0.56 \mathrm{dS} \mathrm{m}^{-1}, \mathrm{pH}$ of 7.6 , total dissolved solid of $338 \mathrm{mg} \mathrm{L}^{-1}$, total $\mathrm{N}$ of $0.3 \mathrm{mg} \mathrm{L}^{-1}$, total dissolved $\mathrm{P}$ of $0.06 \mathrm{mg} \mathrm{L}^{-1}, \mathrm{NO}_{3}-\mathrm{N}$ of $0.1 \mathrm{mg} \mathrm{L}^{-1}, \mathrm{NH}_{4}-\mathrm{N}$ of $<0.1 \mathrm{mg} \mathrm{L}^{-1}$, and $\mathrm{PO}_{4}-\mathrm{P}$ of $0.03 \mathrm{mg} \mathrm{L}^{-1}$. Nutrient concentrations of baseline samples were used to correct nutrient concentration in runoff samples.

A $0.52-\mathrm{m} \times 1.06-\mathrm{m}$ runoff plot was established within each experimental plot using a metal case. This metal case encloses the upper three sides of the plot. A trough made from polyvinyl chloride (PVC) pipe was installed into the downslope direction of the runoff plot to collect water. Four rain gauges were set along the corners of the runoff plot to measure rainfall. During each wet run, time to start runoff and total runoff volume were recorded. Runoff depth was calculated using the runoff volume and runoff plot area. Infiltration rate was calculated as the difference between rainfall depth and runoff over simulation duration. On the eroded soil in Iowa, runoff occurred on only three switchgrass and three no-till corn plots. However, at the pivot corner for the Nebraska site, runoff occurred in all plots. On the eroded soil, plots with no runoff had runoff collector installed on relatively flat soil ( $4 \%$ slope) compared with other plots and collectors. Runoff samples from the water collector were transferred to large buckets and vigorously shaken to distribute sediment uniformly, and two subsamples were taken in 1-L plastic bottles. The bottles were kept in a cooler before transporting them to the laboratory for storage and analysis. One of the runoff samples was used to determine concentrations of sediment and sedimentassociated $\mathrm{C}$ and $\mathrm{N}$, whereas the other sample was used to determine $\mathrm{NO}_{3}-\mathrm{N}, \mathrm{NH}_{4}-\mathrm{N}, \mathrm{PO}_{4}-\mathrm{P}$, and total dissolved $\mathrm{P}$.

Runoff samples were oven dried at $60^{\circ} \mathrm{C}$ for $\sim 3$ wk to determine sediment concentration using the evaporation method (Blanco-Canqui et al., 2004). Oven-dried sediments were scraped, ground to pass through sieves with 2-mm openings, and analyzed for sediment-associated $\mathrm{C}$ and $\mathrm{N}$ concentrations using the dry combustion method (Nelson and Sommers, 1996) in a Flash $2000 \mathrm{C}$ and $\mathrm{N}$ analyzer (CE Elantech). Runoff samples were analyzed for $\mathrm{pH}$ using the 4500-H electrometric method (Rice et al., 2012). Electrical conductivity was determined using the $2520 \mathrm{~B}$ test method. Total dissolved $\mathrm{P}$ was determined directly through inductively coupled Ar plasma (ICAP). An ICAP runs total analysis on elements that are in solution. For runoff water, analysis was conducted in solution samples after decantation. Samples were filtered through Whatman No. 40 filter paper if particulates were observed in the supernatant (Kleinman et al., 2007). The $\mathrm{NH}_{4}-\mathrm{N}$ in runoff water was determined using the $4500 \mathrm{NH}_{3}-\mathrm{H}$ flow injection analysis, whereas $\mathrm{NO}_{3}-\mathrm{N}$ was determined using the $4500 \mathrm{NO}_{3} \mathrm{Cd}$ reduction flow injection method (Rice et al., 2012).

Residue cover in WSGs and no-till corn treatments at both sites was measured using the line-transect method at the time of rainfall simulation to establish their relationship with water quality parameters and soil properties. Two 30.5-m diagonal transects were used, and the presence of residue was recorded at every $0.30 \mathrm{~m}$ to determine the percentage residue cover. The rainfall was simulated in spring when risks for water erosion are high due to limited corn residue cover in corn and when WSGs are in the early stages of breaking spring dormancy.

\section{Soil Sampling and Analysis}

We also analyzed selected soil physicochemical properties related to soil erodibility in the upper 10-cm soil depth (Table 1). Specifically, soil cores were taken using hand probes from four corners adjacent to runoff plots within each experimental plot prior rainfall simulation and composited by plot. Soil samples were used to determine bulk density, wet aggregate stability, cation exchange capacity, $\mathrm{NO}_{3}-\mathrm{N}$, available $\mathrm{P}$, exchangeable $\mathrm{K}$, and total $\mathrm{C}$ and $\mathrm{N}$.

Bulk density was determined by the core method (Grossman and Reinsch, 2002), and porosity was calculated from bulk density, assuming soil particle density of $2.65 \mathrm{~g} \mathrm{~cm}^{-3}$. A portion of the soil samples was air dried and sieved through a $2-\mathrm{mm}$ sieve for $\mathrm{NO}_{3}-\mathrm{N}, \mathrm{P}, \mathrm{K}$, and total $\mathrm{C}$ and $\mathrm{N}$ analysis. The soil $\mathrm{NO}_{3}-\mathrm{N}$ was determined using the $\mathrm{Cd}$ reduction method with a flow injection analyzer (Gelderman and Beegle, 1998). Soil P was determined by the Olsen $\mathrm{HCO}_{3}-\mathrm{P}$ test, whereas $\mathrm{K}$ was determined using the ammonium acetate method (Brown, 1998; Warncke and Brown, 1998). Concentration of total $\mathrm{C}$ and $\mathrm{N}$ was determined by the dry combustion method in a Flash $2000 \mathrm{C}$ and N analyzer (CE Elantech; Nelson and Sommers, 1996).

To determine wet aggregate stability, a fraction of air-dried soil samples was sieved through 4.75- and 8-mm sieves to collect 4.75- to 8-mm aggregates. Approximately $50 \mathrm{~g}$ of soil aggregates was placed on a stack of sieves with 4.75-, 2.0-, 1.0-, 0.5-, and 0.25 -mm-diam. openings, saturated for $10 \mathrm{~min}$ by capillarity followed by water sieving for $10 \mathrm{~min}$ using a wet sieving apparatus generating 30 strokes (3-cm up and down strokes) $\mathrm{min}^{-1}$ (Nimmo and Perkins, 2002). Soil from each sieve was transferred to a glass beaker, oven dried at $105^{\circ} \mathrm{C}$, and corrected for sand content. The fraction of each aggregate size was used to determine mean weight diameter of water-stable aggregates (MWD; Nimmo and Perkins, 2002).

\section{Data Analysis}

All analyses were conducted using SAS 9.4 (SAS Institute, 2015). Data were analyzed for normal distribution using a Shapiro-Wilk test in PROC UNIVARIATE in SAS. Nonnormal data were transformed to make data distribution as normal as possible. For the eroded site, replication with no runoff data was deemed an outlier and excluded in statistical analysis (Dr. Kent Eskridge, personal communication, 2018). Sediment and total dissolved P data from the eroded soil were square root transformed, whereas $\mathrm{PO}_{4}-\mathrm{P}$ was transformed as the reciprocal of square root of data. At the center pivot corner, sediment data were inverse transformed, time to runoff, $\mathrm{NH}_{4}-\mathrm{N}$, and total dissolved $\mathrm{P}$ were transformed as the reciprocal of square root of data, and $\mathrm{PO}_{4}-\mathrm{P}$ was square root transformed. Statistical differences of water quality parameters and soil properties for corn and WSG treatments were analyzed by site using PROC MIXED in SAS. Statistical differences were reported at $\alpha=0.05$, unless otherwise indicated. Pearson's correlation coefficient was performed using CORR, and 
stepwise regression was conducted using STEPWISE in SAS to evaluate the relationship of sediment and nutrients in runoff with soil properties and residue cover.

\section{Results}

\section{Runoff and Sediment Loss}

Time to runoff start (Fig. 1A and 1B) and runoff depth (Fig. 1C and 1D) did not differ between WSG and corn treatments at both sites. Differences in sediment loss between corn and switchgrass were significant at the center pivot corner in Nebraska, but not on the eroded soil in Iowa (Table 2). At the pivot corner, sediment loss was highest in corn and lowest in 'Liberty' switchgrass. Sediment loss at this site decreased in the following order: 'Liberty' $\leq$ low-diversity mix $\leq$ 'Shawnee' $\leq$ corn. The amount of sediment lost decreased by $89 \%$ under 'Liberty' switchgrass, $82 \%$ under low-diversity mix, and 68\% under 'Shawnee' switchgrass compared with no-till corn.

\section{Nutrient Loss}

Sediment-associated total $\mathrm{C}$ and $\mathrm{N}$ losses did not differ between corn and WSG treatments at both sites (Table 2). Dissolved nutrients in runoff did not differ between switchgrass and corn on the eroded soil (Table 2). On this eroded soil in Iowa, the mean concentration of different nutrients in surface runoff was $0.15 \mathrm{mg}$ $\mathrm{NO}_{3}-\mathrm{N}, 0.62 \mathrm{mg} \mathrm{NH}_{4}-\mathrm{N}, 0.26 \mathrm{mg} \mathrm{PO}_{4}-\mathrm{P}$, and $0.36 \mathrm{mg}$ total dissolved $\mathrm{P} \mathrm{L}^{-1}$. However, at the pivot corner in Nebaska, $\mathrm{NO}_{3}-\mathrm{N}$ and $\mathrm{PO}_{4}-\mathrm{P}$ (Table 2) loss differed significantly between WSGs and corn. The $\mathrm{NO}_{3}-\mathrm{N}$ loss occurred in the following order: corn > 'Liberty' = 'Shawnee' $=$ low-diversity mix. The $\mathrm{NO}_{3}-\mathrm{N}$ loss from the corn field was $0.2 \pm 0.01 \mathrm{~kg} \mathrm{ha}^{-1}$, but the $\mathrm{NO}_{3}-\mathrm{N}$ loss under the WSG treatments was below the detection limit $\left(<0.1 \mathrm{mg} \mathrm{L}^{-1}\right)$. At this site, $\mathrm{PO}_{4}-\mathrm{P}$ loss occurred in the following order: corn $>$ 'Shawnee' $\geq$ 'Liberty' $\geq$ low-diversity mix. The $\mathrm{NO}_{3}-\mathrm{N}$ concentration in surface runoff was $0.95 \mathrm{mg} \mathrm{L}^{-1}$ and $\mathrm{PO}_{4}-\mathrm{P}$ was $0.17 \mathrm{mg}$ $\mathrm{L}^{-1}$ under corn. The low diversity mix reduced $\mathrm{PO}_{4}-\mathrm{P}$ loss in runoff by $90 \%$, whereas the monocultures reduced the loss by up to $83 \%$, compared with corn.

\section{Relationship of Sediment and Nutrient Losses in Runoff with Residue Cover and Soil Properties}

On the eroded soil in Iowa, there was no significant difference in residue cover between corn and 'Liberty' switchgrass treatments (Fig. 2A). At the same site, soil bulk density, MWD, $\mathrm{NO}_{3}-\mathrm{N}$, and soil $\mathrm{C}$ and $\mathrm{N}$ concentrations did not differ between WSGs and corn (Table 1).

At the pivot center corner in Nebraska, residue cover differed between corn and WSG treatments (Fig. 2B, $p<0.1$ ). At this site, residue cover was $34 \%$ higher under WSG treatments compared with corn. For example, 'Liberty' switchgrass had 91\% residue cover, whereas corn had only 55\% residue cover. Similar to the eroded soil, bulk density was not different between corn and WSG treatments at the pivot corner, but WSG treatments increased MWD by $75 \%$ compared with corn ( 2.21 vs. $0.56 \mathrm{~mm}$ ) (Table 1 ). Soil $\mathrm{NO}_{3}-\mathrm{N}$ concentration was $80 \%$ higher in corn than in WSG treatments ( 34 vs. $7 \mathrm{mg} \mathrm{kg}^{-1}$ ). At this site, there was no difference in total soil $\mathrm{C}$ and $\mathrm{N}$ concentration among treatments (Table 1).

Table 3 showed that on the eroded soil in Iowa, residue cover was negatively correlated with $\mathrm{PO}_{4}-\mathrm{P}(p<0.05, r=0.86)$. At 

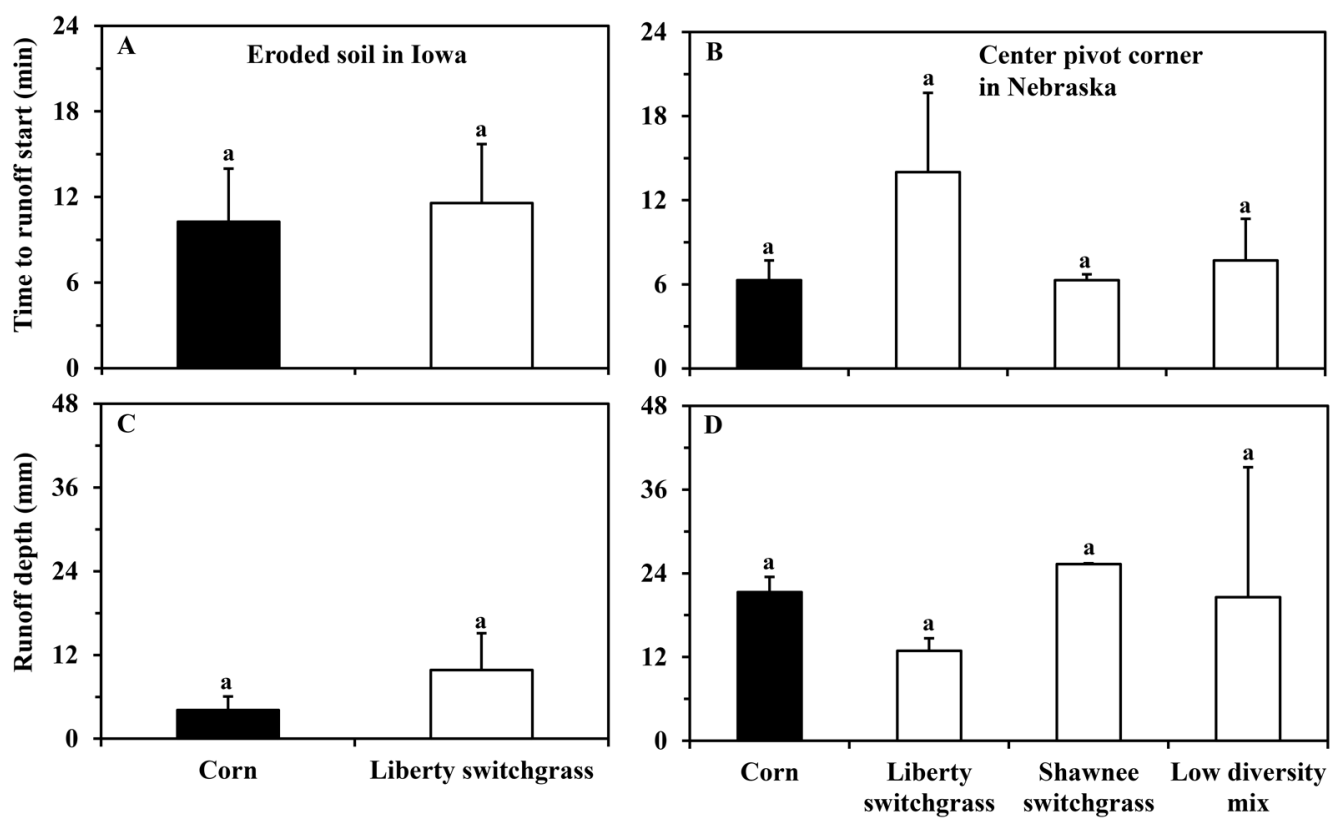

Fig. 1. Warm-season grasses and no-till corn effects on time to runoff start and runoff (A, C) on an eroded soil and (B, D) at a center pivot corner. Bars followed by different lowercase letters are significantly different at a $P$ value of $\leq 0.05$. Error bars are the standard deviation of the mean.

the center pivot corner in Nebraska, MWD was negatively correlated with sediment-associated $\mathrm{C}(p<0.1, r=0.65), \mathrm{NO}_{3}-\mathrm{N}$ $(p<0.05, r=0.90)$, and $\mathrm{PO}_{4}-\mathrm{P}$ loss $(p<0.1, r=0.68)$. Similarly, at this site, residue cover was negatively correlated with $\mathrm{NO}_{3}-\mathrm{N}$ $(p<0.05, r=0.93)$, and $\mathrm{PO}_{4}-\mathrm{P}(p<0.05, r=0.91)$. As residue cover increased, $\mathrm{PO}_{4}-\mathrm{P}$ loss decreased at both sites (Table 3).

Stepwise regression analysis showed that there was no significant soil variable that can predict nutrients lost on the eroded soil. However, sediment loss can be predicted using bulk density, MWD, and residue cover as shown in Eq. [1]. Bulk density explained $68 \%$ of the variation in sediment loss.

Sediment loss $=-1.3+0.94($ bulk density $)$

$$
\begin{aligned}
& -0.05(\text { mean weight diameter })+0.003(\text { residue cover }) ; \\
& r^{2}=1
\end{aligned}
$$

At the center pivot corner, MWD and residue cover were the significant predictors of sediment and nutrient loss as shown in Eq. [2]:

$$
\begin{aligned}
& \text { Sediment loss }=1.48-0.24 \text { (mean weight diameter }) \\
& -0.16(\text { residue cover }) ; r^{2}=0.93
\end{aligned}
$$

Residue cover explained $51 \%$ of variation, whereas MWD explained $42 \%$ of variation in sediment loss. The MWD was a significant predictor of sediment-associated $\mathrm{C}(37 \%), \mathrm{NO}_{3}-\mathrm{N}$ (82\%), and $\mathrm{PO}_{4}-\mathrm{P}(60 \%)$ loss.

\section{Discussion}

\section{Runoff and Sediment Loss}

Results from this study suggest that the impacts of growing perennial native WSGs on water-induced soil erosion when grown in marginally productive croplands as dedicated energy crops can be site specific. For example, WSGs reduced sediment and nutrient losses compared with corn at the center pivot corner, but not on the eroded soil (Table 2). The lower sediment loss in runoff from WSGs than from corn at the pivot corner site supports our first hypothesis that WSGs reduce sediment loss relative to corn. However, the data did not support our hypothesis for the eroded soil.

The limited or lack of differences in time to runoff start and runoff depth in this study at both sites (Fig. 1) could be explained by the lack of significant differences in near-surface soil properties such as bulk density and porosity among treatments (Table 1). In

\begin{tabular}{|c|c|c|c|c|c|c|c|c|}
\hline Environment & Treatment & Sediment & Total C & Total N & $\mathrm{NO}_{3}-\mathrm{N}$ & $\mathrm{NH}_{4}-\mathrm{N}$ & $\mathrm{PO}_{4}-\mathrm{P}$ & $\begin{array}{c}\text { Total } \\
\text { dissolved } \mathrm{P}\end{array}$ \\
\hline & & $\mathrm{kg} \mathrm{ha}^{-1}$ & & & $\mathrm{gha}$ & 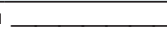 & & $\overline{-}$ \\
\hline \multirow[t]{2}{*}{ Eroded soil in lowa } & 'Liberty' switchgrass & $124 \pm 113 a \dagger$ & $4,560 \pm 960 a$ & $290 \pm 60 a$ & $9.86 \pm 5 \mathrm{a}+$ & $47.53 \pm 41 a$ & $30.42 \pm 22 \mathrm{a}$ & $36.91 \pm 28 a$ \\
\hline & Corn & $155 \pm 94 a$ & $5,570 \pm 3,040 a$ & $440 \pm 240 a$ & $8.41 \pm 5 a$ & $37.68 \pm 39 a$ & $7.46 a \pm 4 a$ & $11.17 \pm 3 a$ \\
\hline \multirow{4}{*}{$\begin{array}{l}\text { Center pivot corner } \\
\text { in Nebraska }\end{array}$} & 'Liberty' switchgrass & $80 \pm 10 c$ & $4,990 \pm 1,150 a$ & $220 \pm 70 a$ & BDLb $\neq$ & $25.76 \pm 4 a$ & $6.19 \pm 3 b c$ & $8.38 \pm 8 a$ \\
\hline & 'Shawnee' switchgrass & $230 \pm 49 a b$ & $11,650 \pm 2,780 a$ & $550 \pm 240 a$ & BDLb & $38.01 \pm 18 a$ & $8.84 \pm 5 b$ & $5.07 \pm 4 a$ \\
\hline & Low-diversity mix & $125 \pm 37 b c$ & $7,510 \pm 4,240 a$ & $320 \pm 100 a$ & BDLb & $24.31 \pm 13 a$ & $3.75 \pm 4 c$ & $2.06 \pm 2 \mathrm{a}$ \\
\hline & Corn & $709 \pm 446 a$ & $22,300 \pm 10,540 a$ & $1,730 \pm 830 a$ & $202 \pm 10 a$ & $120 \pm 3 a$ & $36.70 \pm 13 a$ & $54.44 \pm 7 a$ \\
\hline
\end{tabular}
addition, at the eroded soil site in Iowa, the plant residue cover

Table 2. Warm-season grasses and no-till corn effects on sediment, sediment-associated total $\mathrm{C}$ and $\mathrm{N}$, and other dissolved nutrient (mean $\pm \mathrm{SD}$ ) losses in surface runoff on an eroded soil in lowa and at a center pivot corner in Nebraska.

† Means followed by different letters in a column within the study site are significantly different at $P \leq 0.05$.

\# BDL, below detection limit $\left(<0.1 \mathrm{mg} \mathrm{L}^{-1}\right)$. 

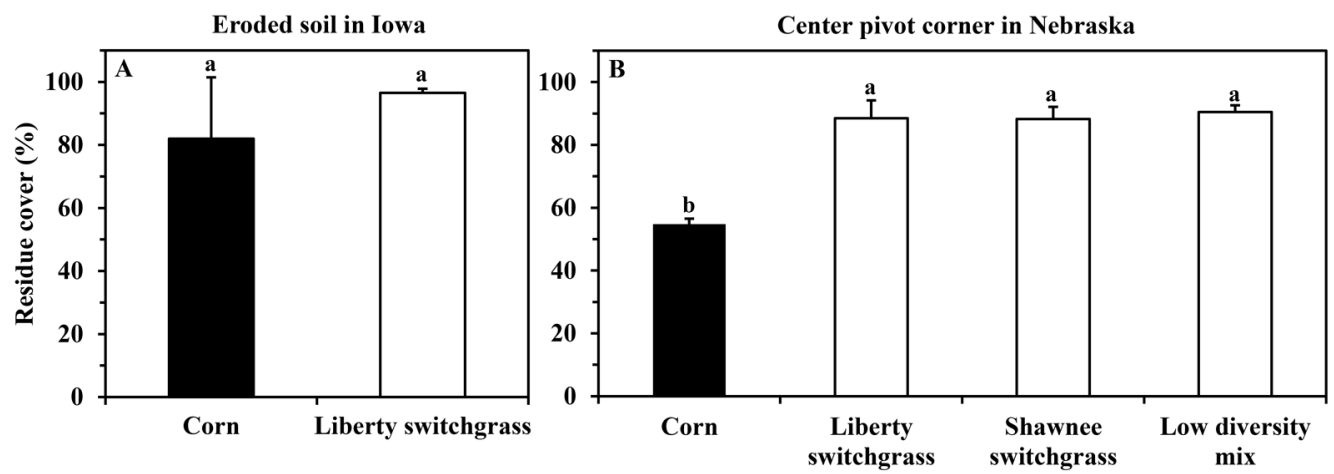

Fig. 2. Mean residue cover in warm-season grasses and corn (A) on an eroded soil and (B) at a center pivot corner during late spring 2017. The warm-season grasses were harvested in the previous autumn to a $10-\mathrm{cm}$ stubble height. Bars followed by different lowercase letters are significantly different at a $P$ value of $\leq 0.1$. Error bars are the standard deviation of the mean.

showed no significant differences between 'Liberty' switchgrass and corn (Fig. 2). Soil porosity dictates the amount of water infiltration and thus runoff. Moreover, runoff amount among replications within the treatments was highly variable, partly due to natural heterogeneity, which reduced statistical differences. Runoff data from both sites, however, showed some trends and suggested that WSGs could delay runoff start and reduce runoff compared with corn. Aboveground biomass and accumulation of plant debris near the soil surface could increase water detention time and infiltration (Blanco-Canqui et al., 2004). Such effects are largely seen during the plant growing season versus during spring when plants are dormant. Our results are consistent with Nyakatawa et al. (2006) reporting no significant effects of switchgrass and corn on runoff (volume) under similar soil texture and slope. On the eroded soil, the lack of significant differences in the concentration of sediment and dissolved nutrients in runoff could be attributed to the lack of differences in plant residue cover (Fig. 2), and soil properties between WSGs and corn (Table 1). It is well recognized that soil erosion decreases exponentially with residue cover (Lindstrom, 1986; Helmers et al., 2012).

The lower sediment loss under WSG treatments at the pivot corner in Nebraska (Table 2) may be due to the higher residue cover and MWD under switchgrass compared with corn at this site. Results from stepwise regression indicate that changes in soil structural quality appear to be the main drivers of sediment and nutrient losses in runoff. This is expected, as increased soil aggregate detachment can lead to greater risks of water erosion (Acharya and Blanco-Canqui, 2018). The critical role of residue cover in reducing sediment loss at both sites also corroborates that an increase in residue cover with WSGs such as switchgrass can result in reduced sediment losses relative to row crops, which can have reduced residue cover, particularly in spring before planting. Residue cover at the center pivot corner in Nebraska was 34\% greater (Fig. 2) and MWD was 75\% greater (Table 1) under WSGs than under corn. Plant canopy and residue cover can intercept rainfall and runoff, as well as reduce soil detachment and protect the surface-exposed macropores (Lindstrom, 1986). Perennial WSGs are expected to improve soil aggregation through deeper and dense root systems, and through increased soil organic matter and residue-derived organic binding agents. At this site, WSGs probably improved wet aggregate stability through increased residue cover and root biomass, although we did not quantify the amount of root biomass. However, previous studies from the same region found that WSGs can produce a significant amount of root biomass (Kibet et al., 2016).

\section{Nutrient Loss}

The lower $\mathrm{NO}_{3}-\mathrm{N}$ and $\mathrm{PO}_{4}-\mathrm{P}$ loss in runoff water under WSG treatments at the center pivot corner (Table 2) supports our hypothesis that WSGs can reduce nutrient losses relative to corn in marginally productive lands. The lower $\mathrm{NO}_{3}-\mathrm{N}$ loss in runoff at this site is possibly due to $80 \%$ higher near-surface $\mathrm{NO}_{3}-\mathrm{N}$ concentration from $\mathrm{N}$ fertilization in corn than in WSG treatments (Table 1). For instance, in 2016, corn received 1.4 times more $N$ than the WSG treatments at this site. Indeed, Sharma and Chaubey (2017) stated that switchgrass can have two to three times less $\mathrm{NO}_{3}-\mathrm{N}$ loss in surface runoff than in corn because it has lower $\mathrm{N}$ fertilizer requirement than annual row crops. In this study, $\mathrm{NO}_{3}-\mathrm{N}$ loss

Table 3. Pearson's correlation coefficients among different near-surface soil properties, surface runoff, sediment, and dissolved nutrients for an eroded soil and a center pivot corner.

\begin{tabular}{|c|c|c|c|c|c|c|c|c|c|}
\hline Environment & Measurements & Runoff & Sediment & Total C & Total N & $\mathrm{NO}_{3}-\mathrm{N}$ & $\mathrm{NH}_{4}-\mathrm{N}$ & $\mathrm{PO}_{4}-\mathrm{P}$ & $\begin{array}{c}\text { Total } \\
\text { dissolved } \mathrm{P}\end{array}$ \\
\hline \multirow[t]{4}{*}{ Eroded soil } & Bulk density & $-0.85^{*}$ & $0.76+$ & 0.12 & 0.30 & $-0.76 \dagger$ & -0.48 & 0.49 & $-0.78 \dagger$ \\
\hline & Water-stable aggregates & 0.50 & 0.02 & $0.83^{*}$ & 0.66 & 0.32 & 0.48 & -0.12 & 0.46 \\
\hline & Residue cover & 0.10 & 0.14 & -0.41 & -0.49 & -0.38 & -0.53 & $-0.86^{*}$ & 0.43 \\
\hline & Runoff & & $-0.78 \dagger$ & 0.05 & -0.22 & $0.75+$ & 0.71 & -0.56 & $0.92+$ \\
\hline \multirow{4}{*}{$\begin{array}{l}\text { Center pivot } \\
\text { corner }\end{array}$} & Bulk density & 0.45 & 0.08 & -0.19 & 0.25 & -0.24 & -0.20 & -0.13 & -0.37 \\
\hline & Water-stable aggregates & -0.10 & 0.59 & $-0.65^{*}$ & 0.59 & $-0.90^{*}$ & $0.68+$ & $-0.68^{*}$ & 0.39 \\
\hline & Residue cover & -0.14 & 0.59 & -0.54 & 0.58 & $-0.93^{*}$ & $0.79 *$ & $-0.91^{*}$ & $0.64 \dagger$ \\
\hline & Runoff & & -0.61 & 0.35 & -0.57 & 0.09 & -0.50 & 0.33 & -0.36 \\
\hline
\end{tabular}

* Significant at the 0.05 probability level.

† Significant at the 0.1 probability level. 
$\left(0.2 \mathrm{~kg} \mathrm{ha}^{-1}\right)$ was lower than that reported by other studies under similar soil texture and slope (Joslin and Schoenholtz, 1997; Nyakatawa et al., 2006). Similarly, the higher $\mathrm{PO}_{4}-\mathrm{P}$ loss from corn than from WSG treatments at the pivot corner (Table 2) may be due to lower residue cover (Fig. 2) and water-stable aggregates, and higher fertilizer input for corn. The decrease in $\mathrm{PO}_{4}-\mathrm{P}$ loss with an increase in residue cover (Table 3 ) highlights the positive role of crop residues in protecting soil against water erosion. On the eroded soil, no significant difference in $\mathrm{NO}_{3}-\mathrm{N}, \mathrm{PO}_{4}-\mathrm{P}$, and total dissolved $\mathrm{P}$ loss in runoff under switchgrass and corn appears to be consistent with soil $\mathrm{NO}_{3}-\mathrm{N}$ and available $\mathrm{P}$ concentrations. A major reason for the lack of effects on soil nutrients could be the short-term nature of the experiment.

\section{Monoculture Cultivars and Monoculture versus Polycultures: Impacts on Water Erosion}

The lack of differences in time to runoff start, runoff (Fig. 1), and nutrient losses (Table 2) between the two monoculture cultivars ('Liberty' and 'Shawnee' switchgrass) at the pivot corner in Nebraska may be due to the absence of significant differences in plant residue cover and near-surface soil properties. There are no measured data on the impact of different monoculture cultivars on water erosion to compare with our results. This clearly warrants additional field studies to fully understand the effects of WSG cultivars on water erosion.

The lack of significant effects of low-diversity mix and monoculture cultivars on runoff, sediment, and nutrient losses (Table 2) did not generally support our second hypothesis, which stated that the low-diversity mix would reduce runoff and losses of sediment and nutrients compared with monocultures. The lack of significant differences in plant residue cover (Fig. 2) and near-surface soil properties (e.g., total C, aggregate stability) between the low-diversity mix and monoculture cultivars (Table 1) can partly explain the similarities in water erosion between both treatments. Studies assessing water erosion between polyculture and monoculture of WSGs are unavailable to compare with our findings. Some compared changes in soil properties between polycultures and monocultures. Fornara and Tilman (2008) found greater soil C storage under high-diversity grassland than under monocultures in a 12-yr experiment in Minnesota. However, Kibet et al. (2016) found no significant differences in soil organic $\mathrm{C}$ and total $\mathrm{N}$ concentrations between monoculture and polyculture WSGs after 6 yr of management in eastern Nebraska.

\section{Warm-Season Grasses and Soil Erodibility Properties}

Results from this study suggest that the effects of WSGs on near-surface soil properties related to erodibility vary with sites (Table 1). For instance, MWD increased under WSG treatments compared with corn at the center pivot corner, which is consistent with earlier studies (Stewart et al., 2015). However, WSGs had no effect on MWD on the eroded soil, possibly due to the short period of time $(<4 \mathrm{yr})$ following WSG establishment. Perennial native WSGs probably increased aggregate stability at the pivot corner through increased residue cover and possibly through high density of fibrous roots. In Nebraska, Blanco-Canqui et al. (2017) reported that WSG treatment had 37\% greater MWD than corn, indicating lower erosion risks under WSGs. The MWDs under corn and WSG treatments at both sites are similar to those values reported by Blanco-Canqui et al. (2014, 2016). Similar to our results, Stewart et al. (2015) observed no difference in soil properties between 'Cave-in-Rock' and 'Trailblazer' switchgrass under similar soil texture in eastern Nebraska. However, Jacobs et al. (2015) found significant difference in water-stable aggregates between 'Alamo' and 'Cave-in Rock' switchgrass after 4 yr of management in west-central Arkansas. The two studies suggest that WSG cultivars can have inconsistent effects on soil properties, requiring further assessment. The negative correlation between MWD and residue cover with $\mathrm{NO}_{3}-\mathrm{N}$ and $\mathrm{PO}_{4}-\mathrm{P}$ loss suggests that WSGs could improve water quality depending on surface residue cover.

Comparison between the two sites suggests that switchgrass had a high tendency to increase P losses at the Iowa site, due to high soil P concentrations. Results generally show lower sediment and sediment-associated $\mathrm{C}$ and $\mathrm{N}$ losses (Table 2) on the eroded soil compared with the center pivot corner, which is consistent with lower runoff (Fig. 1) and higher infiltration on the eroded soil. The water infiltration associated with 'Liberty' switchgrass on the eroded soil was $54 \mathrm{~mm} \mathrm{~h}^{-1}$, whereas the infiltration was $38 \mathrm{~mm}$ $\mathrm{h}^{-1}$ at the pivot corner. Lower infiltration probably translated into higher surface runoff at the pivot corner. In addition, residue cover was higher on the eroded soil than in the pivot corner, which could have reduced runoff and sediment losses.

The results of this study have important implications for water quality management and overall ecosystem health. Our results indicate that WSGs can be grown to improve water quality in marginally productive croplands, but the impacts could be site specific. Although modeling studies indicate that growing perennial grasses in marginal lands could improve water quality by reducing runoff, sediment, and nutrient losses, field results from this and other studies indicate some variable effects (Acharya and Blanco-Canqui, 2018). Additional field data, particularly from marginal lands, are needed to further understand the sitespecific performance of WSGs. These data are also needed to validate results from modeling studies.

\section{Conclusions}

This study comparing water erosion impacts of WSGs (switchgrass) and no-till corn on an eroded soil and a center pivot corner indicates that WSGs as dedicated bioenergy crops have potential to improve water quality in marginally productive croplands, but the impacts are site specific. For example, switchgrass did not reduce sediment and nutrient losses compared with corn on the eroded soil, but on a center pivot corner, it significantly reduced sediment, $\mathrm{NO}_{3}-\mathrm{N}$, and $\mathrm{PO}_{4}-\mathrm{P}$ losses and increased soil aggregate stability compared with corn treatment. Results indicate that WSGs may not reduce either time to runoff start and runoff compared with corn. They also suggest that polyculture such as the low-diversity mix may have limited advantage over switchgrass monoculture for reducing water erosion. Our finding from the pivot corner also suggests that, although switchgrass monocultures can reduce water erosion relative to no-till corn, water erosion among switchgrass monocultures may be the same. Higher residue cover and MWD under WSG treatments compared with corn may have partly contributed to the reduction in water erosion at the pivot corner. The lack of significant difference in water erosion between corn and switchgrass treatments on the eroded soil was possibly due to the lack of difference in 
residue cover and near-surface soil properties among treatments. Overall, perennial WSGs can reduce risks of water erosion in spring compared with corn, but their effectiveness can be site specific, depending on the amount of surface cover and improvement in soil properties.

\section{Acknowledgments}

This study was supported by funding from the North Central Regional Sun Grant Center at South Dakota State University through a grant provided by the USDA under Award no. 2014-38502-22598 and through the USDA National Institute of Food and AgricultureAgriculture and Food Research Initiative-Coordinated Agricultural Projects (NIFA-AFRI-CAP) Grant no. 2011-68005-30411. The authors thank the Steckly family for providing access and field assistance at the on-farm pivot corner site in Nebraska.

\section{References}

Acharya, B.S., and H. Blanco-Canqui. 2018. Lignocellulosic-based bioenergy and water quality parameters: A review. GCB Bioenergy 10:504-533. doi: $10.1111 / \mathrm{gcbb} .12508$

Blanco-Canqui, H., C.J. Gantzer, S.H. Anderson, E.E. Alberts, and A.L. Thompson. 2004. Grass barrier and vegetative filter strip effectiveness in reducing runoff, sediment, nitrogen, and phosphorus loss. Soil Sci. Soc. Am. J. 68:1670-1678. doi:10.2136/sssaj2004.1670

Blanco-Canqui, H., J.E. Gilley, D.E. Eisenhauer, P.J. Jasa, and A. Boldt. 2014. Soil carbon accumulation under switchgrass barriers. Agron. J. 106:2185-2192. doi: 10.2134/agronj14.0227

Blanco-Canqui, H., R.B. Mitchell, V.L. Jin, M.R. Schmer, and K.M. Eskridge. 2017. Perennial warm-season grasses for producing biofuel and enhancing soil properties: An alternative to corn residue removal. GCB Bioenergy 9:1510-1521. doi: $10.1111 / \mathrm{gcbb} .12436$

Blanco-Canqui, H., A.L. Stalker, R. Rasby, T.M. Shaver, M.E. Drewnoski, S. van Donk, and L. Kibet. 2016. Does cattle grazing and baling of corn residue increase water erosion? Soil Sci. Soc. Am. J. 80:168-177. doi:10.2136/sssaj2015.07.0254

Brown, C., T. Griggs, T. Keene, M. Marra, and J. Skousen. 2016. Switchgrass biofuel production on reclaimed surface mines: I. Soil quality and dry matter yield. BioEnergy Res. 9:31-39. doi:10.1007/s12155-015-9658-2

Brown, J.R., editor. 1998. Recommended chemical soil test procedures for the North Central Region. North Central Reg. Publ. 221 (revised). Univ. Missouri Agric. Exp. Station, Columbia.

Feng, Q., I. Chaubey, Y.G. Her, R. Cibin, B. Engel, J. Volenec, and X. Wang. 2015. Hydrologic and water quality impacts and biomass production potential on marginal land. Environ. Model. Softw. 72:230-238. doi:10.1016/j. envsoft.2015.07.004

Fidel, R.B., D.A. Laird, and T.B. Parkin. 2017. Impact of six lignocellulosic biochars on $\mathrm{C}$ and $\mathrm{N}$ dynamics of two contrasting soils. GCB Bioenergy 9:1279-1291. doi: $10.1111 / \mathrm{gcbb} .12414$

Fornara, D.A., and D. Tilman. 2008. Plant functional composition influences rates of soil carbon and nitrogen accumulation. J. Ecol. 96:314-322. doi: $10.1111 / j .1365-2745.2007 .01345 . x$

Gelderman, R.H., and D. Beegle. 1998. Nitrate-nitrogen. In: J.R. Brown, editor, Recommended chemical soil test procedures for the North Central Region. North Central Reg. Publ. 221 (revised). Univ. Missouri Agric. Exp. Station, Columbia. p. $17-20$.

Gelfand, I., R. Sahajpal, X. Zhang, R.C. Izaurralde, K.L. Gross, and G.P. Robertson. 2013. Sustainable bioenergy production from marginal lands in the US Midwest. Nature 493:514-517. doi:10.1038/nature11811

Grossman, R.B., and T.G. Reinsch. 2002. Bulk density and linear extensibility. In: J.H. Dane and G.C. Topp, editors, Methods of soil analysis: Part 4. Physical methods. SSSA Book Ser. 5.4. SSSA, Madison, WI. p. 201-225. doi:10.2136/ sssabookser5.4.c9

Helmers, M.J., X. Zhou, H. Asbjornsen, R. Kolka, M.D. Tomer, and R.M. Cruse 2012. Sediment removal by prairie filter strips in row-cropped ephemeral watersheds. J. Environ. Qual. 41:1531-1539. doi:10.2134/jeq2011.0473

Humphry, J.B., T.C. Daniel, D.R. Edwards, and A.N. Sharpley. 2002. A portable rainfall simulator for plot-scale runoff studies. Appl. Eng. Agric. 18:199-204. doi: $10.13031 / 2013.7789$

Jacobs, A., K.R. Brye, R. King, J. Douglas, L.S. Wood, L.C. Purcell, and M. Looper. 2015. Switchgrass management practice effects on near-surface soil properties in west-central Arkansas. Open J. Soil Sci. 5:69-86. doi:10.4236/ojss.2015.53008

Jiang, M., B.S. Felzer, and D. Sahagian. 2016. Predictability of precipitation over the conterminous US based on the CMIP5 multi-model ensemble. Sci. Rep. 6:29962. doi:10.1038/srep29962
Joslin, J.D., and S.H. Schoenholtz. 1997. Measuring the environmental effects of converting cropland to short-rotation woody crops: A research approach. Biomass Bioenergy 13:301-311. doi:10.1016/S0961-9534(97)10017-4

Kibet, L., H. Blanco-Canqui, R.B. Mitchell, and W.H. Schacht. 2016. Root biomass and soil carbon response to growing perennial grasses for bioenergy. Energy Sustain. Soc. 6:1. doi:10.1186/s13705-015-0065-5

Kleinman, P., D. Sullivan, A. Wolf, R. Brandt, Z. Dou, H. Elliott, et al. 2007. Selection of a water-extractable phosphorus test for manures and biosolids as an indicator of runoff loss potential. J. Environ. Qual. 36:1357-1367. doi:10.2134/jeq2006.0450

Lee, K.H., T.M. Isenhart, and R.C. Schultz. 2003. Sediment and nutrient removal in an established multi-species riparian buffer. J. Soil Water Conserv. 58:1-8.

Lindstrom, M.J. 1986. Effects of residue harvesting on water runoff, soil erosion and nutrient loss. Agric. Ecosyst. Environ. 16:103-112. doi:10.1016/0167-8809(86)90097-6

Mitchell, R., K.P. Vogel, and D.R. Uden. 2012. The feasibility of switchgrass for biofuel production. Biofuels 3:47-59. doi:10.4155/bfs.11.153

Morton, L.W., J. Hobbs, J.G. Arbuckle, and A. Loy. 2015. Upper Midwest climate variations: Farmer responses to excess water risks. J. Environ. Qual. 44:810-822. doi: $10.2134 /$ jeq2014.08.0352

Nelson, D.W., and L.E. Sommers. 1996. Total carbon, organic carbon and organic matter: Laboratory methods. In: D.L. Sparks, et al., editors, Methods of soil analysis: Part 3. Chemical methods. SSSA Book Ser. 5.3. SSSA and ASA, Madison, WI. p. 961-1010. doi:10.2136/sssabookser5.3.c34

Nimmo, J.R., and K.S. Perkins. 2002. Aggregate stability and size distribution. In: J.H. Dane and G.C. Topp, editors, Methods of soil analysis: Part 4. Physical methods. SSSA Book Ser. 5.4. SSSA, Madison, WI. p. 317-327. doi:10.2136/ sssabookser5.4.c14

Nyakatawa, E.Z., D.A. Mays, V.R. Tolbert, T.H. Green, and L. Bingham. 2006. Runoff, sediment, nitrogen, and phosphorus losses from agricultural land converted to sweetgum and switchgrass bioenergy feedstock production in north Alabama. Biomass Bioenergy 30:655-664. doi:10.1016/j. biombioe.2006.01.008

Porter, P.A., R.B. Mitchell, and K.J. Moore. 2015. Reducing hypoxia in the Gulf of Mexico: Reimagining a more resilient agricultural landscape in the Mississippi River watershed. J. Soil Water Conserv. 70:63A-68A. doi:10.2489/jswc.70.3.63A

Rice, E.W., R.B. Baird, A.D. Eaton, and L.S. Clesceri, editors. 2012. Standard methods for the examination of water and wastewater. 22nd ed. Am. Public Health Assoc., Am. Water Works Assoc., and Water Environ. Fed., Washington, DC.

SAS Institute. 2015. The SAS system for Windows. Release 9.3. SAS Inst., Cary, NC.

Saunders, S., D. Findlay, T. Easley, and T. Spencer. 2012. Doubled trouble: More Midwestern extreme storms. The Rocky Mountain Clim. Org., Louisville, CO, Nat. Resour. Defense Counc., New York.

Schilling, K.E., M.K. Jha, Y.K. Zhang, P.W. Gassman, and C.F. Wolter. 2008. Impact of land use and land cover change on the water balance of a large agricultural watershed: Historical effects and future directions. Water Resour. Res. 44:11851202. doi:10.1029/2007WR006644

Sharma, S., and I. Chaubey. 2017. Surface and subsurface transport of nitrate loss from the selected bioenergy crop fields: Systematic review, analysis and future directions. Agriculture 7:27. doi:10.3390/agriculture7030027

Stackpoole, S.M., E.G. Stets, D.W. Clow, D.A. Burns, G.R. Aiken, B.T. Aulenbach, et al. 2017. Spatial and temporal patterns of dissolved organic matter quantity and quality in the Mississippi River basin, 1997-2013. Hydrol. Processes 31:902915. doi: 10.1002/hyp.11072

Stewart, C.E., R.F. Follett, E.G. Pruessner, G.E. Varvel, K.P. Vogel, and R.B. Mitchell. 2015. Nitrogen and harvest effects on soil properties under rainfed switchgrass and no-till corn over 9 years: Implications for soil quality. GCB Bioenergy 7:288-301. doi:10.1111/gcbb.12142

Thomas, M.A., L.M. Ahiablame, B.A. Engel, and I. Chaubey. 2014. Modeling water quality impacts of growing corn, switchgrass, and miscanthus on marginal soils. J. Water Resour. Prot. 6:1352. doi:10.4236/jwarp.2014.614125

USEPA. 2007. Hypoxia in the northern Gulf of Mexico: An update by the EPA science advisory board. EPA-SAB-08-003. USEPA, Washington, DC.

VanLoocke, A., T.E. Twine, C.J. Kucharik, and C.J. Bernacchi. 2017. Assessing the potential to decrease the Gulf of Mexico hypoxic zone with Midwest US perennial cellulosic feedstock production. GCB Bioenergy 9:858-875. doi:10.1111/ gcbb.12385

Warncke, D., and J.R. Brown. 1998. Potassium and other basic cations. In: J.R. Brown, editor, Recommended chemical soil test procedures for the North Central Region. North Central Reg. Publ. 221 (revised). Univ. Missouri Ag. Exp. Station, Columbia. p. 31-33.

Zaibon, S., S.H. Anderson, A.L. Thompson, N.R. Kitchen, C.J. Gantzer, and S.I. Haruna. 2017. Soil water infiltration affected by topsoil thickness in row crop and switchgrass production systems. Geoderma 286:46-53. doi:10.1016/j. geoderma.2016.10.016

Zhou, X., M.J. Helmers, H. Asbjornsen, R. Kolka, M.D. Tomer, and R.M. Cruse. 2014. Nutrient removal by prairie filter strips in agricultural landscapes. J. Soil Water Conserv. 69:54-64. doi:10.2489/jswc.69.1.54 